\title{
The Model of Competitive Advantage Development in Private Islamic Education Institutions
}

\author{
Hifza $^{1}$, Aslan $^{1}$ \\ ${ }^{1}$ Sultan M. Syafiuddin Sambas Institute of Islamic Religion, Indonesia \\ (e-mail: Hifzahamdan2018@gmail.com, aslanmarani88@yahoo.com)
}

\begin{abstract}
This study aimed to find out the model for developing competitive advantage in institutions of private Islamic education of the Ar-Raihan Bantul and Integrated Islamic Elementary School (SDIT) Luqman Al-Hakim Yogyakarta. The findings showed that the development model competitive edvantage in private Islamic educational institutions as follows: First, the main ideas of competitive superiority was to build integrated religious-based of basic education for preparing a generation of superior golden qurani. Second, the foundation of education refers back on Alquran and Sunah that demands for change and challenges of Muslims in the global era, optimization of basic potential students. The orientation of competitive dominance was for long-term, the life in world and the hereafter. Third, the approach used was humanist and development of potential human resources based on religion. Fourth, the characteristics of excellence was the integration of a culture of academic and religious quality, as well as the uniqueness of schools through tahfiz AlQur'an. Fifth, the strategy of developing competitive advantage was the focus on differentiation based religious.
\end{abstract}

Key words: Model Development, Competitive advantage, Private Islamic Education Institution.

\section{Introduction}

Islamic educational institutions are the places for the ongoing educational process that aims to increase the faith, understanding, appreciation and experience of students on Islam so that Muslims become faithful and devoted to God, Allah and have good character in their private lives, in the nation and society. [1] Formal Islamic educational institutions, including Raudhatul Athfal, madrassas, Islamic schools, and tertiary institutions, while non-formal ones, such as diniyah takmiliyah, diniyah education in pesantren, and pesantren itself. While nonformal Islamic educational institutions are Islamic education in the community, in the form of recitals, majelis taklim and so forth. [2]

In the context of formal Islamic educational institutions, there are those who are public or under the auspices of the government and those who are private or established by the community. Judging from the growth and development to date, most are still in quite poor conditions, especially in Islamic educational institutions that are private or in remote areas. [3] Issues that surround the private Islamic education institution, are also increasingly complex from time to time. [4] 
The issue of cause and effect that continues to accompany the journey of Islamic educational institutions, makes many madrassas and Islamic schools with private status unable to survive for a long time. If these problems continue to be ignored, the existence of private Islamic education institutions will continue to decline. Therefore, the educational institution must be able to take a stand and take strategic steps to get out of such conditions, so that the problem of cause and effect that continues to envelop the Islamic educational institution can be resolved.

No less important is the need for every Islamic educational institution to have a competitive advantage, namely the ability to produce a product or service that is valued more by the customer than the competing institution. [5] Therefore, every Islamic educational institution that is private, must be able to find and develop core institutional competencies in order to be able to obtain and maintain competitive advantage. [6]

The study of competitive excellence of educational institutions has been widely studied in previous research. Mazzarol and Soutar examine the development of mental models in building sustainable competitive advantage in educational institutions. [7] Curran focuses on identifying and exploring things that encourage the formation of higher education institutions' competitive advantage. [8] David Wijaya studies on human resource management based on teacher competency in order to improve school competitiveness. [9] Mainardes focuses on proposing a model that can explain the process of identifying competitive advantage in Higher Education Institutions. [10] Lynch and Baines focuses on strategy development in higher education, towards resource-based competitive advantages. [11].

Competitive advantage, according to Porter, is the ability of an organization to achieve economic benefits over the profits achieved by competitors in the same industry or service activity. [5] compared to competing institutions. [12] Meanwhile, Dogre and Vickrey mentioned that competitive advantage has two different but interrelated meanings. The first understanding emphasizes excellence or superior in terms of resources and capabilities owned by the institution, while the second understanding emphasizes excellence in achieving performance. [13] [14]

Competitive advantage in terms of the superiority of resources and institutional capabilities according to Jay Barney has several criteria, namely: 1) Valuable, namely the resources and capabilities possessed enable the institution to implement strategies that can improve organizational effectiveness and efficiency; 2) Rare, i.e. resources and capabilities are rarely owned by competitors; 3 ) Inimitable, i.e. resources and capabilities are hard to be imitated by competitors; and 4) Nonsubstitutable, i.e. resources and capabilities owned are difficult to be replaced with other resources or capabilities. [15]

Glueck and Jauch mention that competitive advantage can be developed by analyzing and diagnosing management to determine the strengths and weaknesses of facing opportunities and threats by focusing on marketing and distribution, R\&D and engineering, production and operations, resources and employees, as well as financial and accounting advantages. [16] The principles of developing competitive advantage include HR, processes, information technology, strategy, and knowledge management. [6]

Competitive advantage can actually be created if the organization can find and develop core competencies that include skills, knowledge, and technology. If combined with a strategic process (strategic process) will form a core capabilities, so that business processes are able to provide high-value products or services to customers. [6]

The strategies that can be considered in the process of building an organization's competitive advantage according to Porter are cost leadership strategy, differentiation strategies, and a focus strategy. [5] A differentiation focus strategy aims to make 
differentiation only within one or a small group of targeted market segments, while the cost focus strategy is an effort to find advantages with lower costs in a small group of certain market segments. [17]

The existence of private Islamic education institutions that are superior and continue to experience positive developments, can be seen among others from the development of two private schools, namely SDIT Ar-Raihan Bantul and SDIT Luqman Al-Hakim Yogyakarta. [18] The rapid development of SDIT Ar-Raihan Bantul and SDIT Luqman Al-Hakim Yogyakarta shows that the two schools are so serious in institutional arrangement that they still exist and are able to compete with other educational institutions. The ability to present superior programs and the ability to maintain the sustainability of educational institutions also indicates that SDIT Ar-Raihan Bantul and SDIT Luqman Al-Hakim Yogyakarta already have a competitive advantage.

Therefore, this research focuses on developing competitive advantage models in private Islamic educational institutions, specifically at SDIT Ar-Raihan Bantul and SDIT Luqman AlHakim Yogyakarta.

\section{Method}

This research used a qualitative approach, a type of case study and a multi-site design. Data collection techniques used were in-depth interviews, observation, and documentation. Data analysis was carried out in two stages, namely single site analysis and cross site analysis. Single site data analysis used Milles and Huberman interactive analysis techniques consisting of data reduction, data display, and verification/ conclusion drawing, $\left[{ }^{19}\right]$ while cross-site data analysis used the steps of Robert K. Yin's case study analysis. $\left[{ }^{20}\right]$ Checking the validity of the data uses four techniques, namely: 1) credibility test with triangulation and member checking; 2) dependability; 3) confirmability, and 4) transferability.

\section{$3 \quad$ Results and Discussion}

Based on research findings at the two research loci, the competitive advantage development model at SDIT can be understood from five aspects, namely the concept, foundation and orientation, approach, characteristics, and strategies for developing competitive advantage. Research findings on each site and cross site about the competitive advantage development model on SDIT are as follows:

Table 1. Cross-Site Research Find Matrix SDIT Competitive Advantage Development Model

\begin{tabular}{clll}
\hline Component & \multicolumn{1}{c}{$\begin{array}{c}\text { Findings on } \\
\text { SDIT Ar-Raihan }\end{array}$} & $\begin{array}{l}\text { Findings on SDIT } \\
\text { Luqman Al-Hakim }\end{array}$ & $\begin{array}{c}\text { Cross Site } \\
\text { Findings }\end{array}$ \\
\hline Concept & $\begin{array}{l}\text { Preparing a generation of the } \\
\text { Koran who is smart and } \\
\text { achievers, good in the academic } \\
\text { and non-academic }\end{array}$ & $\begin{array}{l}\text { Making the Koran as } \\
\text { excellence and educational } \\
\text { foundation for giving birth } \\
\text { to a generation that is } \\
\text { intelligent, independent } \\
\text { and achievers } \\
\text { The Koran and the Sunna }\end{array}$ & $\begin{array}{l}\text { Preparing a generation of smart } \\
\text { and achievers of the Qur'an }\end{array}$ \\
Fondation and & Sticking to the Qur'an and & Alquran and Sunna, demands of \\
\hline
\end{tabular}




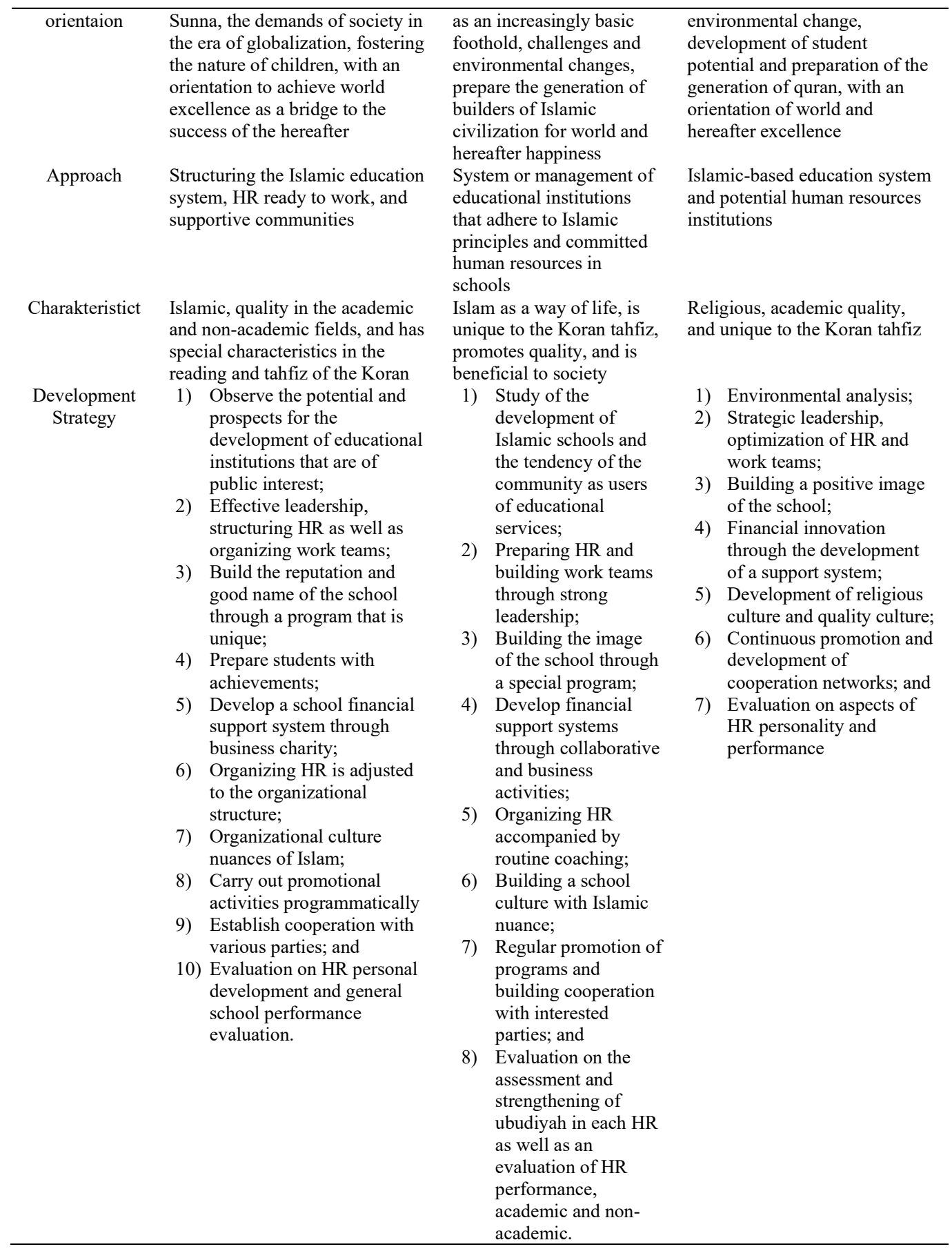

According to David, competitive advantage is the core of the strategic management process.[21]. Dirgantoro stated that competitive advantage grows from the value or benefits the institution can create for customers, where the value is greater than the capital that has 
been spent to create it. [6] Goh said that it is posited that comparative advantages in resources can lead to marketplace positions of competitive advantage, which then lead to a superior performance. [22] Based on the research findings, the model of developing competitive advantage of private Islamic educational institutions is as follows: First, the concept of competitive advantage of institutions is to build an integrated religious-based basic education to give birth to a superior generation of qurani. Based on the criteria of competitive advantage according to Barney, the idea of competitive advantage of educational institutions by building a religious-based basic education integration to produce a golden generation of superior qurani is a valuable and marketable concept of excellence. Competitive advantage that is built based on the values of the Koran is another form of innovation in providing education.

According to Saefudin, educational innovation is a business or process of change that aims to obtain better things in the field of education. The characteristics contained in educational innovation, including: 1) bring up something new; 2) is qualitative; 3) there is an element of intent; and 4) improving capabilities. [23]

Second, the basis of competitive advantage is to return to the Koran and Sunna, the demands of change and the challenges of Muslims in the global era, the optimization of the basic potential of students, and the preparation of a golden generation of the quran, while the orientation of excellence is long-term, namely world and hereafter excellence.

This is in line with the provisions of the Surah Albaqarah (2): 148. The purpose of the Surah Al Baqarah (2): 148 is that God gave orders with the word fastabiqul khairat or "hasten in doing good." Imam An-Nawawi in the book Riyadhush Shalihin put this discussion in a special chapter with the title: "Immediately in doing good and encouragement for people who want to do good to immediately do it with sincerity without the slightest hesitation." [24]

According to Abidin, Islam teaches that the superiority that is pursued should be intrinsic, namely the superiority that drives humans to benefit the universe and bring it to heaven provided by God. [25] In line with this, Kartajaya and Sula emphasize that to build competitive advantage, each Muslims must uphold honesty and the principle of justice, stay away from cheating, do not justify any means in determining competitive strategies, do not vilify competitors, do not slander competitors, and avoid negative cooperation to achieve benefits for either party. [26]

Consideration of competitive advantage in Islamic educational institutions certainly does not stop at the process of forming or producing material excellence. Islamic education is a process of fostering all human potential as creatures of faith and devoted, think, and work, healthy, strong, and highly skilled for the benefit of themselves and their environment. Education becomes a pillar of human empowerment to build a civilization that empties into its form of a socially and socially prosperous social order. [27]

Third, the characteristics of competitive advantage are the integration of a culture of academic and religious quality, as well as the uniqueness of the school through the Qur'anic Qur'an recitation. Religious character shows that the competitive advantage of educational institutions has a valuable nature, because it makes Islam a way of life. Academic quality is a character that is difficult to replace. This is due to the importance of academic quality culture in the process of managing educational institutions. The distinctive character through the Qur'an Koran is the criteria for competitive advantage that is unique and difficult to imitate by others.

The development of competitive advantage in educational institutions is a motivation for every personnel in it to work optimally. In the context of the implementation of Islamic education, the work spirit of a Muslim does not only develop from the demands of the 
empirical reality of modern society, but is based on a religious spirit as part of pious charity which is a prerequisite for his piety. [28] In doing his work, a Muslim is not only for the sake of fulfilling his life but because religion encourages him as a form of devotion to his Lord.

Fourth, the competitive advantage approach is a potential Islamic-based education system and human resources (HR). The effectiveness of competitive advantage through a humanist system approach requires awareness and good interaction with the environment. Management must be careful in maintaining good relationships with service users, government, organizations, and society in general who have the potential to influence the activities of stable educational institutions. The most striking disadvantage of the systems approach is its relationship with measurement and the issue of whether those methods really matter. However, an important advantage of the system approach is its ability to be applied if the final goal is not quantitative. [29]

In relation to the potential HR approach, Terry argues that the principal of this approach is human behavior and brings management to the methods and concepts of relevant social knowledge, especially psychology and anthropology. [30] The concept of social knowledge also includes the personal dynamics of individuals to the relationship with metaphysical forces that exist outside of humans. In Islam, the personal dynamics in question are the relationship between humans and God Almighty. Therefore, the institutional process related to school competitive advantage needs to be emphasized in all human relations and human relations with their Lord.

Fifth, the strategy of developing competitive dominance is the focus of religious-based differentiation. Porter said that the differentiation strategy aimed at buyers in certain markets then positioned the business uniquely to meet these criteria. Focus strategy ifferentiation aims to make differentiation in only one or a small group of targeted market segments and to ensure that customers really have different needs and desires. [31]

Based on Porter's theory, a differentiation focus strategy can be developed into a strategy that is concentrated on making a difference in education services. However, all forms of educational services still rely on internal school resources through the development of core human resource competencies (HR) and the completeness of the curriculum based on the Qur'an's values.

The strategic focus steps of differentiation according to Porter are: 1) differentiating service quality by concentrating on certain segments; 2) product differentiation through exploitation of certain components that are different from other industries; and 3) image differentiation, i.e. with a combination of policies for strategic targets. Therefore, organizations must have special competencies as drivers of organizational performance, so as to create a value that is higher than what competitors have. [31]

While efforts to develop competitive superiority in private Islamic educational institutions include: 1) Environmental analysis; 2) Strategic leadership, optimization of HR and work teams; 3) Building a positive image of the school; 4) Financial innovation through the development of a support system; 5) Development of religious culture and quality culture; 6) Continuous promotion and development of cooperation networks; and 7) Evaluation on aspects of HR personality and performance.

Thus, the strategy for developing competitive advantage of private Islamic educational institutions is a strategy of religious-based differentiation focus, namely with the following steps: 1) differentiation of leadership competencies and human resources; 2) differentiation of cohesiveness in work teams and cooperation networks; 3) differentiation of service quality with financial innovation, religious culture, and quality culture; 4) product differentiation in the Koran curriculum and tahfiz program; and 5) image differentiation through graduates who 
excel in academics and Quran recitation.

The competitive advantage model in private Islamic educational institutions can be described as follows:

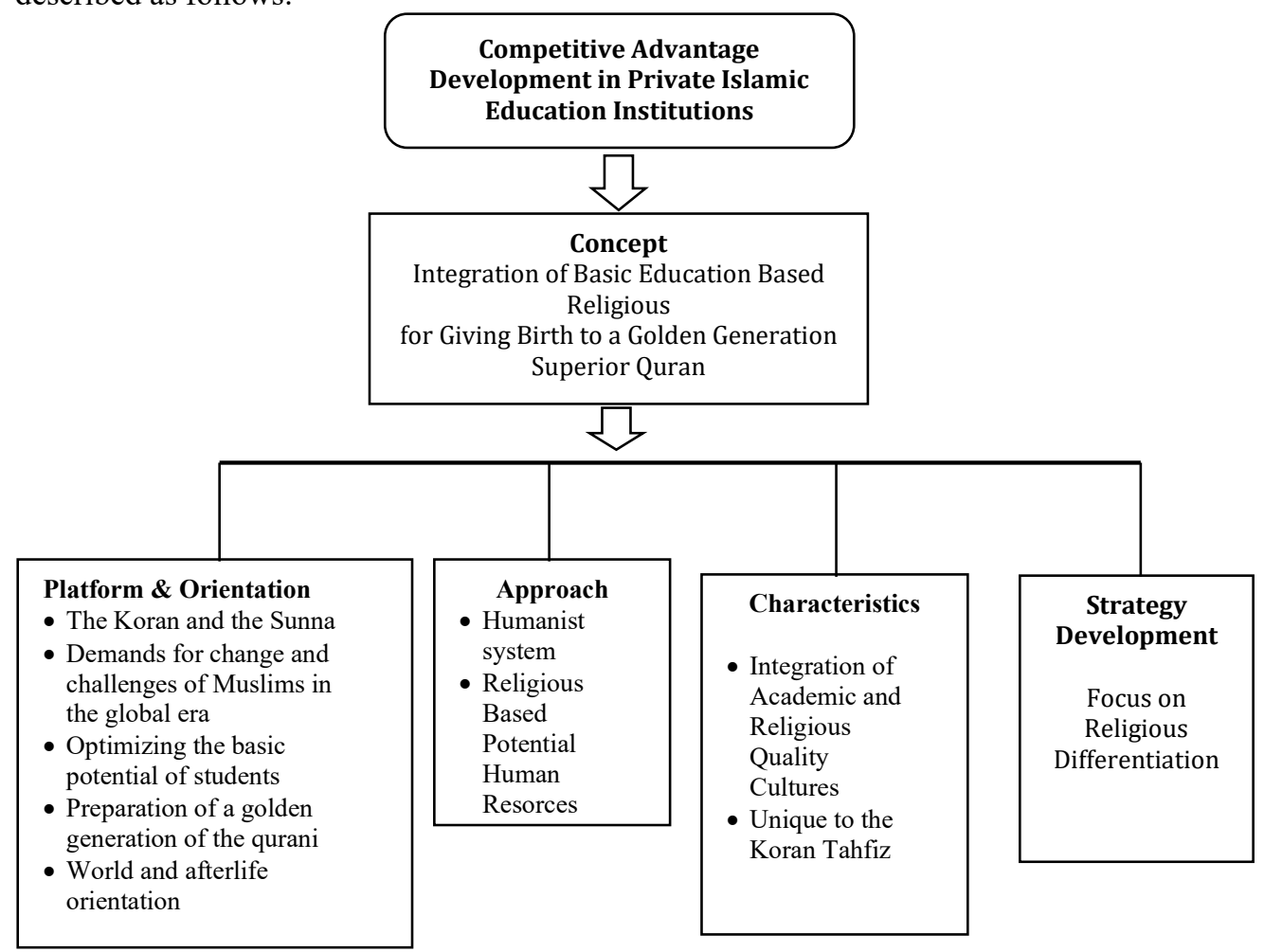

Figure 1. Chart of models for developing competitive advantage in private Islamic educational institutions

Based on this explanation it can be concluded that the model of developing competitive advantage in private Islamic educational institutions develops theories of competitive advantage that have existed before. The development of which lies in the components of the concept, foundation, orientation, approach, characteristics, and development strategies that are always based on Islamic values, so that the model of developing competitive advantage can be taken into consideration for private Islamic educational institutions to achieve and maintain institutional competitive advantage education.

\section{Conclusion}

Based on the description of the model of developing competitive advantage in private Islamic educational institutions, it can be concluded as follows: First, the concept of competitive advantage of private Islamic educational institutions is to build an integrated religious-based basic education to prepare to a superior generation of qurani. Second, the foundation of education is back to the Qur'an and Sunna, the demands of change and the 
challenges of Muslims in the global era, the optimization of the basic potential of students, and the preparation of a golden generation of the quran. The orientation of competitive advantage is long-term, that is, the world and the hereafter. Third, the approach used is humanist and potential religious-based human resource development. Fourth, the characteristics of excellence are the integration of a culture of academic and religious quality, as well as the uniqueness of the school through the Qur'anic Qur'an recitation. Fifth, the strategy of developing competitive advantage is the focus of religious-based differentiation, namely with the following steps: 1) differentiation of leadership competencies and human resources; 2) differentiation of cohesiveness in work teams and cooperation networks; 3) differentiation of service quality with financial innovation, religious culture, and quality culture; 4) product differentiation in the Koran curriculum and tahfiz program; and 5) image differentiation through graduates who excel in academics and Quran recitation.

\section{References}

[1] Muhaimin. Pemikiran Dan Aktualisasi Pengembangan Pendidikan Islam; Rajawali Pers: Jakarta, 2008.

[2] Hawi, A. Tantangan Lembaga Pendidikan Islam. Tadrib J. Pendidik. Agama Islam 2017, III (1), $144-147$.

[3] Intan, N. Masih Banyak Madrasah Yang Kondisinya Memprihatinkan. Republika. co.id, Kolom Khazanah. Kamis. March 15, 2018.

[4] Alma, B.; Hurriyati, R. Manajemen Corporate Dan Strategi Pemasaran Jasa Pendidikan; Alfabeta: Bandung, 2008.

[5] Porter, M. E. Keunggulan Bersaing: Menciptakan Dan Mempertahankan Kinerja Unggul, Terj. Tim Penerjemah Binarupa Aksara; Binarupa Aksara: Jakarta, 1994.

[6] Dirgantoro, C. Manajemen Stratejik: Konsep, Kasus Dan Implementasi; PT. Grasindo: Jakarta, 2007.

[7] Mazzarol, T.; Soutar, G. N. Sustainable Competitive Advantage for Educational Institutions: A Suggested Model. J. Educ. Manag. 1999, 13 (6), 287-300.

[8] Curran, P. J. Competition in UK Higher Education: Competitive Advantage in the Research Assessment Exercise and Porter's Diamond Model. J. High. Educ. Q. SRHE 2000, 54 (4), 295 421.

[9] Wijaya, D. Pemasaran Jasa Pendidikan Sebagai Upaya Untuk Meningkatkan Daya Saing Sekolah. J. Pendidik. Penabur 2008, 11, 69-86.

[10] Mainardes, E. W. Competitive Advantages in Institutions of Higher Education: A Proposal of Research Model," Journal of Academy of Business and Economics Publisher. J. Acad. Bus. Econ. Publ. Int. Acad. Bus. Econ. Audience 2009, 9 (2), 35-50.

[11] Lynch, R.; Baines, P. Strategy Development in UK Higher Education: Towards Resource-based Competitive Advantages. J. High. Educ. Policy Manag. 2004, 26 (2), 171-187.

[12] Raymond A. Noe et.al. Manajemen Sumber Daya Manusia: Menuju Keunggulan Bersaing, Terj. David Wijaya; Salemba Empat: Jakarta, 2010.

[13] Droge, C.; Vickrey, S. Source and Outcomes of Competitive Advantage: An Explanory Study in The Furniture Industry," Dalam Decision Sciences; 1994.

[14] Adhinugroho, H. Sistem Informasi Pemasaran Dan Environmental Scaning Pengaruhnya Terhadap Kualitas Layanan, Keunggulan Bersaing Dan Pertumbuhan Pelanggan. J. Sains Pemasar. Indones. 2010, 1 (3).

[16] Glueck, W. F.; Jauch, L. R. Manajemen Strategi Dan Kebijakan Lembaga, Terj. Murad, 3rd ed; Erlangga: Jakarta, 1994.

[17] , H. Riset SDM Dalam Organisasi; PT. Gramedia Pustaka: Yogyakarta, 1999.

[18] Hifza. Observasi Prapenelitian, 2019.

[19] Meleong, L. J. Metode Penelitian Kualitatif; Remaja Rosdakarya: Bandung, 2008. 
[20] Yin, R. K. Studi Kasus: Desain Dan Metode, Terj. M. Djauzi Mudzakir; Rajawali Press: Jakarta, 2000.

[21] David, F. R. Manajemen Strategis: Konsep, Terj. Ichsan Setio Budi, Ke-10.; Salemba Empat: Jakarta, 2006.

[22] Goh, J. W. P. The Resource Advantage Theory of Competition: Implications for Higher Educational Institutions in Singapore. Educ. Res. Policy Pract. 2003, 2 (2), 93-106.

[23] Saefudin, U. Inovasi Pendidikan; Alfabeta: Bandung, 2008.

[24] An-Nawawi, A.-I. A. Z. Y. bin S. Terjemah Riyadhush Shalihin, Terj. Achmad Sunarto; Pustaka Amani: Jakarta, 2001.

[25] Abidin, S. Z. Kebijakan Publik; Yayasan Pancur Sawah: Jakarta, 2002.

[26] Kertajaya, H.; Sula, M. S. Syari 'ah Marketing; Mizan: Bandung, 2006.

[27] Mas'ud, A. Menggagas Format Pendidikan Nondikotomik; Gama Media: Yogyakarta, 2003.

[28] Effendi, R. Produksi Dalam Islam; Magistra Insania Press: Yogyakarta, 2008.

[29] Johannessen, J.-A.; Olsen, B. Knowledge Management and Sustainable Competitive Advantages: The Impact of Dynamic Contextual Training. Int. J. Inf. Manag. 2003, 23 (4), 277-289.

[30] Terry, G. R. Prinsip-Prinsip Manajemen, Terj. J. Smith D.F.M; Bumi Aksara: Jakarta, 2003.

[31] Porter. Strategi Bersaing: Teknik Menganalisis Industri Dan Pesaing, Terj. Agus Maulana; Erlangga: Jakarta. 